\title{
An Experimental Analysis of a Nano Structured Inorganic Ceramic Membrane for Carbon Capture Applications in Energy Security Challenges
}

\author{
Ngozi C. Nwogu ${ }^{1}$, Mohammed N. Kajama ${ }^{1}, K^{2}$ nnedy Dedekuma ${ }^{1} \&$ Edward Gobina ${ }^{1}$ \\ ${ }^{1}$ Centre for Process Integration and Membrane Technology, IDEAS Research Institute, Robert Gordon \\ University, United Kingdom \\ Correspondence: Professor Edward Gobina, Centre for Process Integration and Membrane Technology, IDEAS \\ Research Institute, The Robert Gordon University, Riverside East Garthdee Road, Aberdeen AB10 7GJ., United \\ Kingdom. Tel: 44-(0)122-4262-437. E-mail: e.gobina@rgu.ac.uk
}

\author{
Received: April 9, 2014 Accepted: May 26, 2014 Online Published: June 10, 2014 \\ doi:10.5539/eer.v4n3p1 URL: http://dx.doi.org/10.5539/eer.v4n3p1
}

\begin{abstract}
Nanostructured hybrid materials have the solution to facilitate renewable energy to cover up for anticipated energy gap and related ecological problems. In this work the design of a nano structured ceramic membrane is carried out using ceramic nanoparticles for application in energy security challenges. However the innovation is that a membrane porous network is modified through its immersion in silica based solution. This process helps to pull the gas of interest towards the membrane in this case $\mathrm{CO}_{2}$ and allows the other gases to pass through. However the development of this hybrid ceramic gas separation membrane in this study elaborates on the recovery of hydrogen from fuel reforming unit for use in fuel cell applications. A detailed production and purification of hydrogen in a fuel processor using the advanced ceramic membrane is presented. A gaseous mixture of hydrogen and carbon dioxide is produced following fuel on-board reforming. To enhance the efficiency of the fuel cell, a clean hydrogen using membranes with a high permeability and selectivity for $\mathrm{H}_{2}$ over $\mathrm{N}_{2}, \mathrm{CO}_{2}$ such that $\mathrm{H}_{2}$ will permeate with high-purity. Accordingly, results obtained show an appreciable high flow rate of $5.045 \mathrm{l} / \mathrm{min}$ and 3.71 separation factor of hydrogen gas to $\mathrm{CO}_{2}$ at relatively low pressure when compared to the other gases. Further confirmation of the dominance of Knudsen and surface flow mechanism in the entire experiments is also presented.
\end{abstract}

Keywords: ceramic membrane, energy security, renewable energy, carbon capture, hydrogen production, gas separation, fuel cell

\section{Introduction}

Carbon dioxide gas, a greenhouse gas has remained a contributor to global climate change. Recent reports from some researchers has shown a drastic increase in the concentration of atmospheric $\mathrm{CO}_{2}$ from approximately 275 to $387 \mathrm{ppm}$ with an annual average increment of $3 \mathrm{ppm}$ in the last century which has resulted in temperature rise. This obviously is an indicator to future warming (Merkel et al., 2010). Therefore the protection and security of our climate is vital especially when there are efforts being put in place to reduce $\mathrm{CO}_{2}$ emissions emanating from fossil fuel utilization which are major emitters. However various technologies are currently being developed to accomplish set goals to minimise global warming, a huge challenge resulting from the continual emission of these greenhouse gases. In this circumstance, identifying the method of capturing atmospheric $\mathrm{CO}_{2}$ using low energy, high level performance and to meet global targets is pertinent (Favre, 2007). Energy security and curtailing energy involvement in global warming are two prevailing tasks being looked at in the power sector to attain high level of global sustainable energy security. Currently records show that about 1400 million people across the world do not have access to essential electricity. The people most affected by lack of electricity supply are those in the remote villages and lack good and hygienic cooking facilities. An example is the sub- Saharan Africa where about $15 \%$ of the world population live. This is a very pathetic and devastating situation to contend with and thus a huge impediment to economic and social growth due to unavailability of state-of-the-art facilities. Urgent attention is therefore needed to effect changes by putting together a combined effort and commitment to actualize and attain set objectives (Kaygusuz, 2012). Fossil fuel which is known globally as a major source of power generation as reported is not sustainable going by the ever growing global economy. In addition fossil fuel 
combustion through human related source has led to very hazardous and catastrophic effect on the earth's atmosphere. In that context, for fast developing and industrialised economies, energy is on high demand and this calls for an uninterrupted, available and affordable energy supply which will stand the test of time. Achieving this level of sustainable energy security and economic performance with current technologies has yielded little or no result in terms of balancing $\mathrm{CO}_{2}$ emission abatement and the economic growth (Sartbaeva et al., 2008). Therefore the use of affordable technology which will be readily available and can provide cheaper and cleaner source of energy can be adapted to meet these challenges. For policies that have interest in fuel effectiveness, the likely option will be to mitigate $\mathrm{CO}_{2}$ emissions. This can be realized from renewable as well as non-renewable energy sources (Favre, 2007). Hydrogen has been identified as an alternative to fossil fuel. As energy carrier, can be produced from renewable sources, namely: wind, solar, biomass and water. Natural gas and coal as non-renewable energy sources also have hydrogen and carbon dioxide as their combustion by-products. Hydrogen utilization has therefore paved way to the fabrication of very operational energy generated device including fuel cell (Edwards et al., 2008). By definition, fuel cell is a device that combines both electrical and chemical energy, whereby a reaction takes place in the presence of oxygen with further reforming process to produce electricity along with combustion by-products (Löffler, 2003). High-efficiency fuel cell operation from clean hydrogen can be utilised in all energy sectors, however its application in vehicular transportation and distributed power are more important. Accordingly fuel cell with clean hydrogen-rich fuel is top among solutions sort for in the transitional process to a $\mathrm{CO}_{2}$-zero emission economy and a pathway to sustainable energy in the nearest future. Production of a cost efficient and sustainable clean hydrogen is among the top challenges which must be surmounted for the evolution from carbon based (fossil fuel) energy economy to hydrogen based economy (Edwards et al., 2008). Therefore an efficient and cost efficient technology for gas separation is highly required that which will have effect on the overall expenditure of the entire system. Membrane technology at the moment is being highly applied widely in hydrogen separation. Membrane applications have remained a more energy efficient substitute to conventional methods in gas separations. The outstanding difference in the flow rate and permeation features during the separation processes involving multi component gas mixtures makes the membrane a good candidate for gas separation (Murkowski, 2012). Generally two different types of membranes exist, organic and inorganic membrane (McCool et al., 2003).

\section{Membrane as a Selective Barrier}

The diagram in Figure 1 depicts a simple gas separation of two gas molecules across a membrane. The feed is a mixture of the two gases going into the upper level of the box and as expected separation takes place in this compartment.

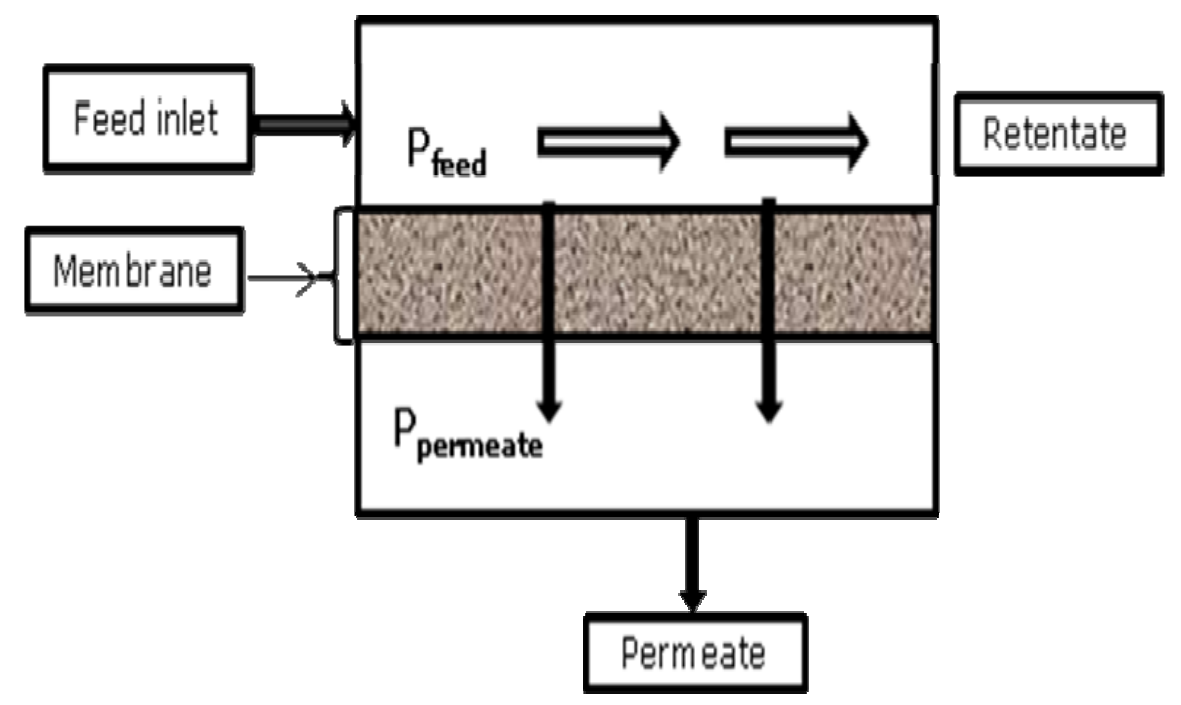

Figure 1. A simplified procedure of membrane separation process 


\section{Experimental}

\subsection{Membrane Material Characterization}

The preparation and fabrication of inorganic ceramic membrane from different materials through various methods results in the development of membrane with distinct physical appearance which is tailored towards achieving a pore size, membrane area and pore size distribution which can be controlled resulting in a higher permeation rate of hydrogen gas with high separation factor. Membrane structure is one of the parameter in determination of membrane characteristics. This is done through scanning electron microscopy which produces micrographs and images. Nanoporous structural make up of the membrane is usually identified by the magnification of these images. Defects determination through cracks or pinholes of the membrane is also achieved; in addition the pore size distribution can be obtained through this means (Othman et al., 2004). The diagram shown below is an outer sectional area of the membrane support with $\times 2000$ magnification.

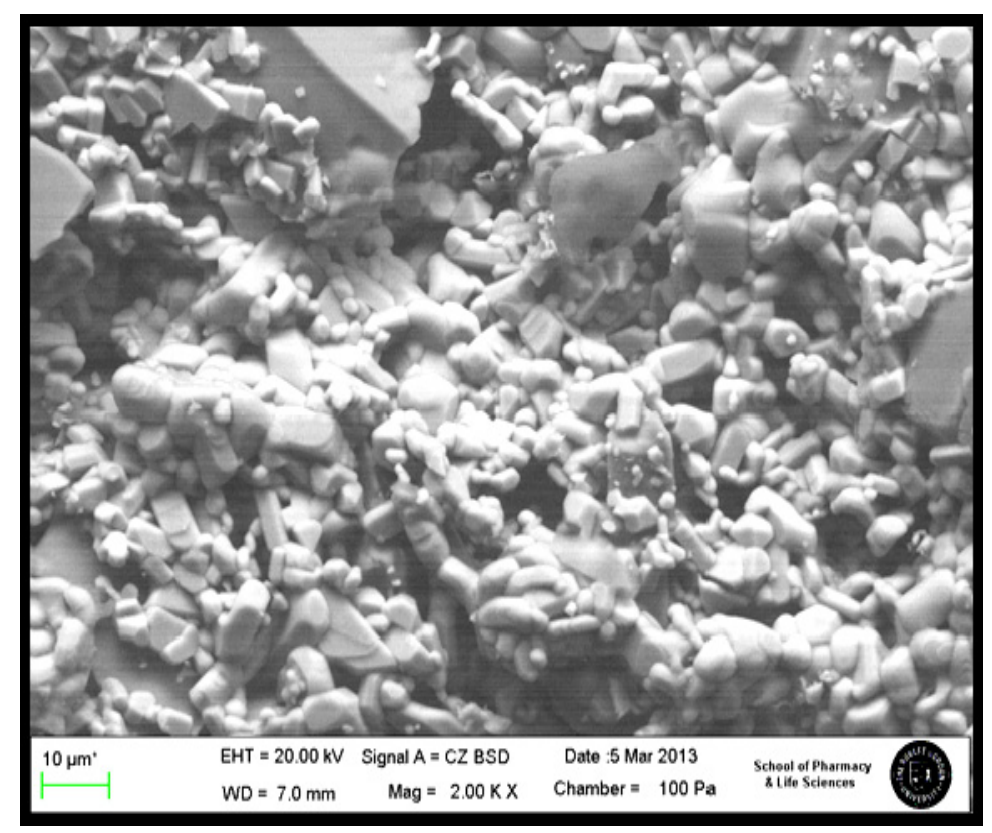

Figure 2. SEM of Membrane support Images with $\times 2000$ Magnification

Consequently, porous ceramic membrane consists of several layers of different materials namely: Aluminium oxide $\left(\mathrm{Al}_{2} \mathrm{O}_{3}\right)$, Titanium Oxide $\left(\mathrm{TiO}_{2}\right)$, Zirconium Oxide $\left(\mathrm{ZrO}_{2}\right)$, Silicon dioxide $\left(\mathrm{SiO}_{2}\right)$, Silicon carbide, Zeolite or a mixture of two materials applied on an underlying porous stainless steel, $\alpha$-alumina, $\gamma$-alumina, zirconium, zeolite supports (Shekhawat et al., 2003). Membrane separation of gases is a highly intricate process and therefore the material used for its preparation should demonstrate a long-lasting feature, stability and tailored in an advanced manner to be adapted to separate specific gases.

Membrane materials characterization can also be determined through the elemental composition of the sample by the analysis of the sample material which is identified using an Energy Dispersive x-ray analysis technique, (EDXA). The EDXA system is attached to the SEM. Data generated by EDXA analyses the true composition of the elements within the sample. Figure 3 shows the EDXA of the nano-structured ceramic membrane used in carrying out the gas permeation experiment. As observed, the elements present are Titanium oxide, silicon oxide and Aluminium Oxide. 


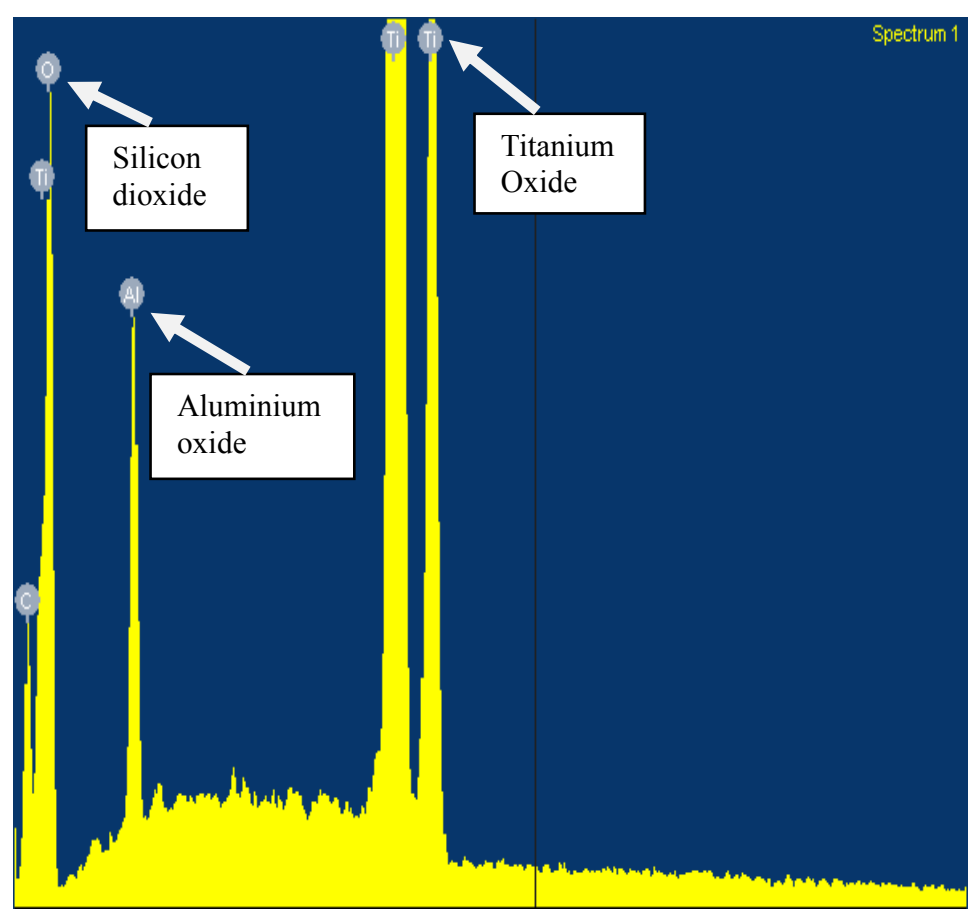

Figure 3. EDXA analysis of membrane sample elemental composition

\subsection{Clean Hydrogen Production through a Fuel Processor}

There are several ways to produce hydrogen gas since it does occur in the system in which it can be used. However in the thermo-chemical process, hydrogen production from fossil fuel or natural gas, its separation and purification are of great importance globally. As an illustration where water to gas shift reaction is involved for converting carbon monoxide to hydrogen, membrane technology show substantial promises for shifting the equilibrium to achieve the purpose. In general membranes are important for the refinement of Hydrogen (Lu et al., 2007). Consequently hydrogen can be produced on an economical scale by steam reforming (a reaction between steam and hydrocarbon) for instance

$$
\mathrm{CH}_{4}+\mathrm{H}_{2} \mathrm{O}=\mathrm{CO}+3 \mathrm{H}_{2} \text {. }
$$

Carbon monoxide further reacts with steam to form $\mathrm{H}_{2}$ and $\mathrm{CO}_{2}$ by the exothermic reaction, which is commonly referred to as the water-gas shift reaction:

$$
\mathrm{CO}+\mathrm{H}_{2} \mathrm{O}=\mathrm{CO}_{2}+\mathrm{H}_{2} \text {. }
$$

Conversely if hydrogen is selectively recovered from the reaction system, the thermodynamic stability of the reaction is moved to the product side where higher conversion of $\mathrm{CH}_{4}$ to $\mathrm{H}_{2}$ and $\mathrm{CO}_{2}$ can be attained at a relatively lower temperature. The characteristic features to achieve high level of $\mathrm{CO}_{2}$ and $\mathrm{H}_{2}$ separation include high separation selectivity, high permeability, the stability and durability of hybrid inorganic ceramic membranes (Xia et al., 2002). 


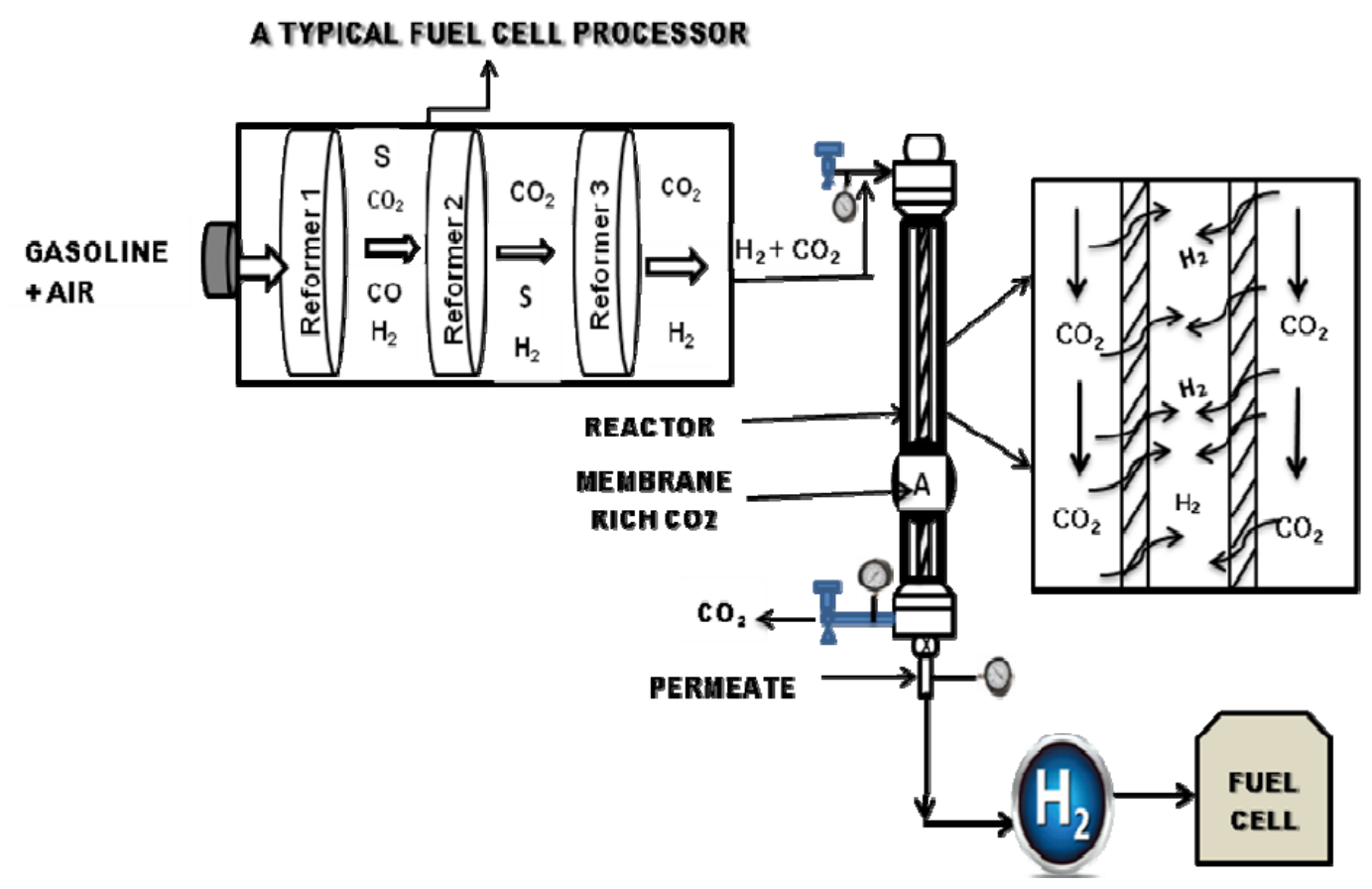

Figure 4. Hydrogen production and purification through a membrane

Figure 4 depicts a schematic diagram of clean hydrogen production through a membrane. It also shows the location of the membrane separation following fuel processing and fuel cell. In the fuel processing unit, the fuel comprises of gasoline in the presence of air and water). The first reformer takes in the syngas involving sulphur, carbondi oxide, carbon monoxide and hydrogen gases. Carbon monoxide is removed in the second reformer in the presence of a carbon monoxide to $\mathrm{H}_{2}$ catalyst. The remaining products is channelled to a sulphur sop-up unit to get rid of the sulphur (Ahmed \& Krumpelt, 2001). In order to achieve hydrogen of high purity from either the syngas or the products of the water-gas shift reaction, separation of $\mathrm{H}_{2}$ from either $\mathrm{CO}$ or $\mathrm{CO}_{2}$ is required. Competitive separation processes for hydrogen from such streams include amine absorption $\left(\mathrm{CO}_{2}\right.$ separation), pressure swing adsorption (PSA) and membrane separation. In the separation of hydrogen from other products in refineries, membrane systems are more economical than PSA in terms of both relative capital investment and unit recovery costs (Spillman, 1989). A gaseous mixture of hydrogen and carbon dioxide is produced following fossil fuel on-board reforming as by-products. At this point an advanced hybrid inorganic membrane is then installed which achieves high recovery of hydrogen over carbon oxide to produce clean hydrogen in a cost effective manner for use in various fuel cell applications. The efficiency of the fuel cell is thus greatly increased with further enhancement in the quest on a sustainable and affordable energy security to achieve a hydrogen economy.

\subsection{Gas Permeation Experiment}

The immersion of a membrane support in a silica based solution and repeated dip coating technique with intervals of hydrothermal treatment procedure has led to the manufacture of hybrid ceramic membrane for the production of clean hydrogen for fuel cell application. In this paper a $15 \mathrm{~nm}$ pore size nano structured modified commercial alumina ceramic membrane with an effective permeable length of $358 \mathrm{~mm}$, outer and inner diameter of $10 \mathrm{~mm}$ and $7 \mathrm{~mm}$ respectively and membrane surface area of $0.0062 \mathrm{~m}^{2}$ was placed in a membrane/reactor as housing with graphite rings as a seal to prevent gas leakages and at the same time enhance accuracy of data obtained. Pressure gauges were connected to the reactor at specified points on the flow line to measure feed, permeate and retentate pressures. This inorganic modified ceramic membrane is formed comprises of plurality of chemically discreet portion. The first part as the separating layer formed from silica oxide and the second the support made of aluminum oxide. The coated layer is used as a separating layer to allow faster permeation of one gas from a gas mixture and also due to its affinity for the gas (Nwogu et al., 2013; Gobina, 2006).

A single gas experiment comprising of $\mathrm{N}_{2}, \mathrm{H}_{2}, \mathrm{CO}_{2}$ and $\mathrm{O}_{2}$ gases was carried out to determine their individual flow rates with respect to pressure. Values obtained were calculated and recorded. Plot generated from the result is shown below. 


\section{Results and Discussion}

Figure 5 shows the plot of the flow rate of $\mathrm{H}_{2}, \mathrm{CO}_{2}, \mathrm{O}_{2}$ and $\mathrm{N}_{2}$ gases versus pressure drop. It can be observed that hydrogen gas permeated faster with increase in feed pressure through the modified ceramic inorganic membrane more than the other three single gases, $\mathrm{O}_{2}, \mathrm{~N}_{2}$ and $\mathrm{CO}_{2} . \mathrm{CO}_{2}$ which has a molecular weight of 44 had the lowest flow rate. The high flow rate of hydrogen however is attributed to its relatively smaller molecular weight in comparison to the other gases which affords its better mobility within the pore network of the membrane as illustrated below:

Flow Rates: $\mathrm{H}_{2}>\mathrm{N}_{2}>\mathrm{O}_{2}>\mathrm{CO}_{2}$

Molecular Weights: $\mathrm{CO}_{2}>\mathrm{O}_{2}>\mathrm{N}_{2}>\mathrm{H}_{2}$

Accordingly hydrogen gas which has a molecular weight of 2 had the highest flow rate of $5.045 \mathrm{l} / \mathrm{min}$ with increase in pressure drop above 4 bars while carbon dioxide of a higher molecular weight 44 attained the lowest flow rate confirming the predominance of Knudsen flow mechanism in the separation process. This also shows that the flow is molecular weight dependent.

Figure 5 also confirms the membrane performance with respect to the gases that permeates faster than the others through the membrane. Generally the more permeable a membrane, the less selective it could be.

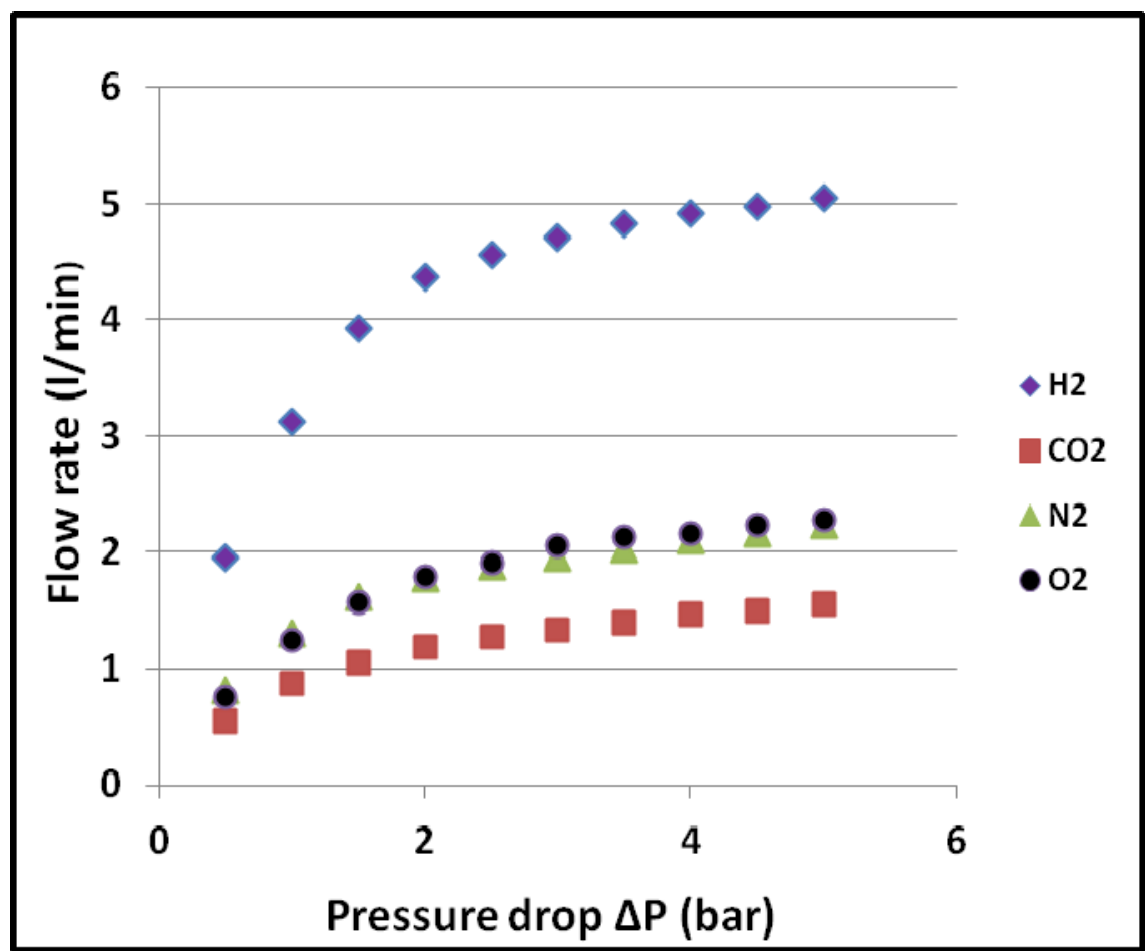

Figure 5. Effect of pressure drop on $\mathrm{H}_{2}, \mathrm{~N}_{2}, \mathrm{CO}_{2}$ and $\mathrm{O}_{2}$ gases flow rate

The inclination of a membrane to allow or pass one gas and not another otherwise known as separation factor, $\alpha$ known as selectivity is also considered in this paper. This was determined through the membrane selectivity of $\mathrm{H}_{2}$ over $\mathrm{CO}_{2}, \mathrm{O}_{2}$ and $\mathrm{N}_{2}$ and given as the ratio of $\mathrm{H}_{2}$ permeance to the other gases. For instance an estimation of $\mathrm{H}_{2}$ selectivity to $\mathrm{CO}_{2}$ can be calculated from the ratio of $\mathrm{H}_{2}$ permeance to that of $\mathrm{CO}_{2}$ given as,

$$
\text { Selectivity, } \alpha=\frac{\text { Permeance of } \mathrm{H}_{2}}{\text { Permeance of } \mathrm{CO}_{2}}
$$

A selectivity factor of 1 is an evidence of no separation, the benchmark therefore in gas mixture selection should be geared towards achieving a selectivity higher than 1 because the more selective a membrane is to a particular gas, the higher the selectivity factor.

Figure 6 is a graphical representation of separation factor obtained in relation to pressure drop for $\mathrm{H}_{2}$ gases over $\mathrm{CO}_{2}, \mathrm{~N}_{2}$ and $\mathrm{O}_{2}$ gases. 


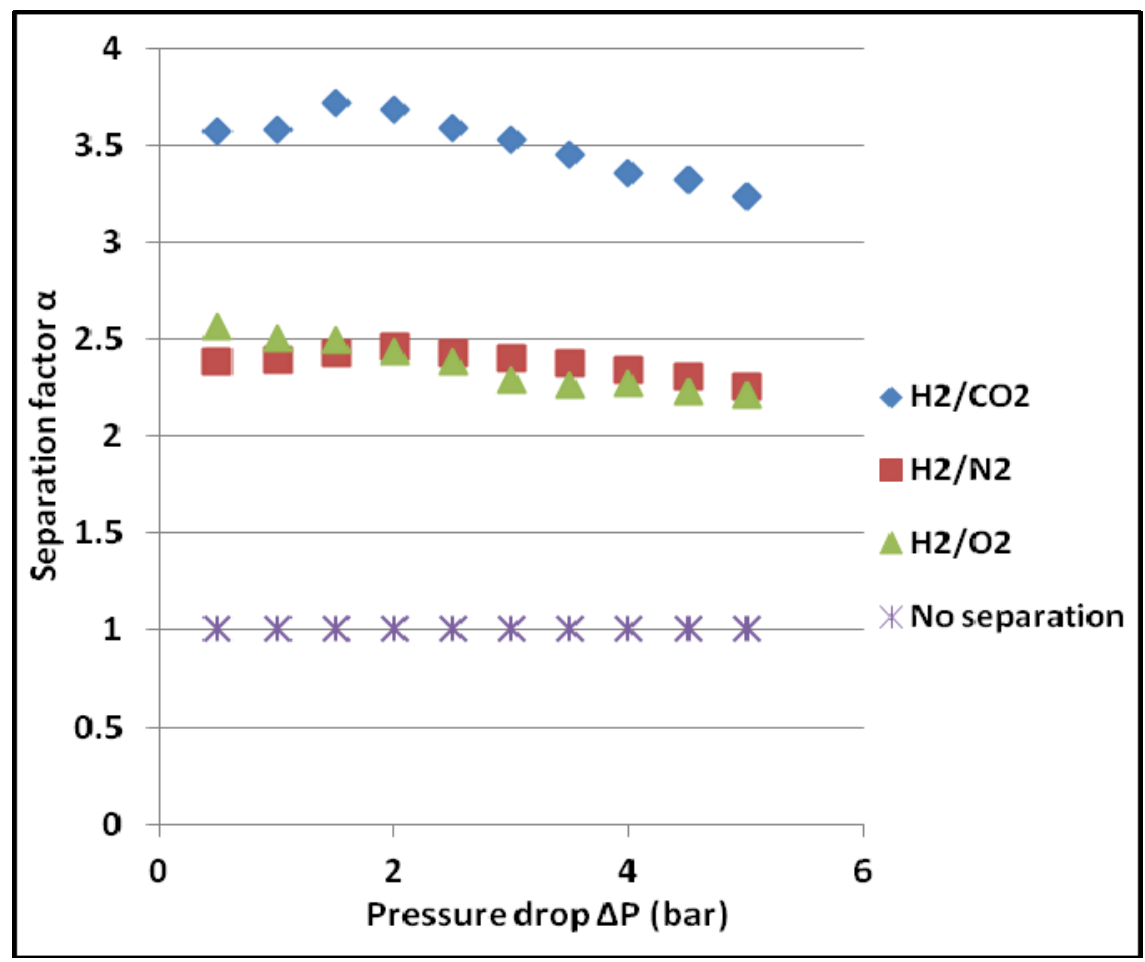

Figure 6. Effect of pressure drop on $\mathrm{H}_{2}$ selectivity over $\mathrm{CO}_{2}, \mathrm{~N}_{2}$ and $\mathrm{O}_{2}$

Figure 6 presents separation factor results of $\mathrm{H}_{2}$ over $\mathrm{CO}_{2}, \mathrm{~N}_{2}$ and $\mathrm{O}_{2}$. A high separation factor of 3.71 was obtained from the gas separation between $\mathrm{H}_{2}$ and $\mathrm{CO}_{2}$; this implies that more $\mathrm{H}_{2}$ will be recovered from $\mathrm{H}_{2}$ and $\mathrm{CO}_{2}$ binary mixtures more than the other three gases.

\section{Conclusions}

Single gas permeation tests carried out have shown that the membrane exhibits good performance and higher permeability of hydrogen gas at low trans-membrane pressure and at room temperature. With 3.71 as the separation factor of $\mathrm{H}_{2}$ to $\mathrm{CO}_{2}$ at a low pressure of $1.5 \mathrm{bar}$, this shows that the membrane has a high level of hydrogen gas selectivity characteristics to $\mathrm{CO}_{2}$ which is a good indication that it can be installed in a fuel processing unit for a high $\mathrm{H}_{2}$ recovery from the rich $\mathrm{CO}_{2}$ stream. Thus the membrane which has several inbuilt characteristic features over other membranes such as high mechanical strength, high chemical stability, easy cleaning, high resistance to acidic chemicals and the ability to withstand high pressure and temperature has the potential in the production of clean hydrogen gas for fuel cell applications for a sustainable and affordable energy security globally.

\section{References}

Ahmed, S., \& Krumpelt, M. (2001). Hydrogen from hydrocarbon fuels for fuel cells. International Journal of Hydrogen Energy, 26(4), 291-301. http://dx.doi.org/10.1016/S0360-3199(00)00097-5

Edwards, P. P., Kuznetsov, V. L., David, W. I., \& Brandon, N. P. (2008). Hydrogen and fuel cells: towards a sustainable energy future. Energy Policy, 36(12), 4356-4362. http://dx.doi.org/10.1016/j.enpol.2008.09.036

Favre, E. (2007). Carbon dioxide recovery from post-combustion processes: can gas permeation membranes compete with absorption? Journal of Membrane Science, 294(1), 50-59. http://dx.doi.org/10.1016/j.memsci.2007.02.007

Gobina, E. (2006). 'A membrane apparatus and method separating gases' (US Patent 7297184 B2), May 23, 2006.

Kaygusuz, K. (2012). Energy for sustainable development: A case of developing countries. Renewable and Sustainable Energy Reviews, 16(2), 1116-1126. http://dx.doi.org/10.1016/j.rser.2011.11.013

Löffler, D. G., Taylor, K., \& Mason, D. (2003). A light hydrocarbon fuel processor producing high-purity hydrogen. Journal of Power Sources, 117(1), 84-91. http://dx.doi.org/10.1016/S0378-7753(03)00357-4 
Lu, G. Q., Diniz da Costa, J. C., Duke, M., Giessler, S., Socolow, R., Williams, R. H., \& Kreutz, T. (2007). Inorganic membranes for hydrogen production and purification: a critical review and perspective. Journal of colloid and interface science, 314(2), 589-603. http://dx.doi.org/10.1016/j.jcis.2007.05.067

McCool, B. A., Hill, N., DiCarlo, J., \& DeSisto, W. J. (2003). Synthesis and characterization of mesoporous silica membranes via dip-coating and hydrothermal deposition techniques. Journal of membrane science, 218(1), 55. http://dx.doi.org/10.1016/S0376-7388(03)00136-4

Merikoski, R. (2012). Flue gas processing in Amine-based capture (pp. 15-16). Tampere University of Technology.

Merkel, T. C., Lin, H., Wei, X., \& Baker, R. (2010). Power plant post-combustion carbon dioxide capture: An opportunity for membranes. Journal of Membrane Science, 359(1), 126-139. http://dx.doi.org/10.1016/j.memsci.2009.10.041

Nwogu, N. C., Gobina, E., \& kajama, M. N. (2013). Improved Carbon dioxide Capture using Nanostructured Ceramic Membranes. Low Carbon Economy Scientific Journal, 4(3), 125-128.

Othman, M. R., Mukhtar, H., \& Ahmad, A. L. (2004). Gas permeation characteristics across nano-porous inorganic membranes. IIUM Eng. J, 5(2), 17-35.

Sartbaeva, A., Kuznetsov, V. L., Wells, S. A., \& Edwards, P. P. (2008). Hydrogen nexus in a sustainable energy future. Energy \& Environmental Science, 1(1), 79-85. http://dx.doi.org/10.1039/b810104n

Shekhawat, D., Luebke, D. R., \& Pennline, H. W. (2003). A review of carbon dioxide selective membranes. US Department of Energy. http://dx.doi.org/10.2172/819990

Spillman, R. W. (1989). Economics of gas separation membranes. Chemical engineering progress, 85(1), 41-62.

Xia, Y, Lu, Y., Kamata, K., Gates, B., \& Yin, Y. (2002). Macroporous materials containing three-dimensionally periodic structures. Macroeconomics for Business and Society: A Developed/developing Country Perspective on the "new Economy", 69.

\section{Copyrights}

Copyright for this article is retained by the author(s), with first publication rights granted to the journal.

This is an open-access article distributed under the terms and conditions of the Creative Commons Attribution license (http://creativecommons.org/licenses/by/3.0/). 